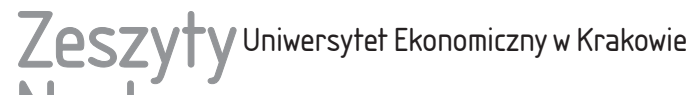 Naukowe
}

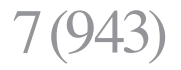

ISSN 1898-6447

Zesz. Nauk. UEK, 2015; 7 (943): 5-24 DOI: 10.15678/ZNUEK.2015.0943.0701

\section{Monika Hamerska}

Uniwersytet Ekonomiczny w Krakowie

\section{Pawet Lula}

Katedra Systemów Obliczeniowych

Uniwersytet Ekonomiczny w Krakowie

\section{Analiza i modelowanie rozwoju naukowego pracowników uczelni}

\section{Streszczenie}

Celem publikacji jest analiza procesu związanego z rozwojem naukowym pracowników uczelni wyższych. Ścieżka kariery naukowej pracownika determinowana jest momentem uzyskania stopnia lub tytułu naukowego oraz obejmowaniem coraz wyższych w hierarchii naukowej stanowisk. Rozwój naukowy zależy od stopnia zaangażowania pracownika, przepisów prawa oraz polityki personalnej prowadzonej w uczelni.

W celu utworzenia modelu rozwoju naukowego autorzy wykorzystali metody analizy przeżycia. Dane wykorzystane do analizy związane są z momentem uzyskania stopnia doktora habilitowanego oraz tytułu profesora przez pracowników Uniwersytetu Ekonomicznego w Krakowie w latach 1970-2014.

Słowa kluczowe: funkcja przeżycia, współczynnik hazardu, rozwój naukowy, uczelnie wyższe.

\section{Wprowadzenie}

Zasadniczym tematem pracy jest analiza procesu rozwoju naukowego postrzeganego przez pryzmat zdobywanych stopni i tytułu naukowego. Autorzy skupili się na badaniu prawdopodobieństwa i czasu niezbędnego do uzyskania stopnia doktora habilitowanego i tytułu profesora. Analizowali również zmiany w tym 
zakresie zachodzące w ostatnich czterech dekadach. Istotność rozwoju naukowego ma wymiar jednostkowy i instytucjonalny. Dla każdego naukowca habilitacja i profesura stanowi przełomowe wydarzenie w życiu, natomiast dla instytucji szkolnictwa wyższego poziom rozwoju naukowego zatrudnianych pracowników określa przypisaną jej kategorię naukową, a tym samym poziom środków na badania i dydaktykę, determinuje uprawnienia dotyczące zakresu działalności dydaktycznej i nadawania stopni naukowych.

Badania empiryczne przedstawione w pracy dotyczą rozwoju naukowego pracowników Uniwersytetu Ekonomicznego w Krakowie i wiedzy powstałej poprzez uogólnienie informacji o rozwoju naukowym ponad pięciuset pracowników naukowo-dydaktycznych tej uczelni zatrudnionych w okresie 1970-2014. Tak duża liczba przeanalizowanych informacji pozwala na sformułowanie pewnych wniosków o charakterze ogólnym dotyczących zarządzania procesem rozwoju naukowego pracowników uczelni.

W warstwie metodycznej pracy autorzy starali się dokonać oceny przydatności metod analizy danych do istoty badanych zjawisk i wynikającego z nich charakteru danych, a w szczególności występowania obserwacji uciętych. W artykule zastosowano metody analizy przeżycia.

\section{Model kariery naukowej nauczyciela akademickiego}

\subsection{Zasady nadawania stopnia doktora habilitowanego i tytułu profesora}

Podstawowym aktem normującym zasady uzyskiwania stopni i tytułów naukowych jest ustawa o stopniach i tytułach naukowych. W analizowanym okresie proces awansów naukowych podlegał zmianom legislacyjnym. Przez pierwsze dwie dekady objęte badaniem obowiązywały przepisy ustawy z dnia 31 marca 1965 r., w której ustawodawca trzykrotnie wprowadzał zmiany legislacyjne. Po 1989 r. system szkolnictwa wyższego w Polsce uległ znacznym zmianom i przekształceniom będącym elementami transformacji i modernizacji całego systemu społeczno-gospodarczego kraju. Jednym z następstw przemian w szkolnictwie wyższym było przyjęcie w 1990 r. nowej ustawy o tytule naukowym i stopniach naukowych. Ustawa z dnia 12 września 1990 r. obowiązywała w niezmienionym kształcie do dnia 1 maja 2003 r. Krótką charakterystykę podstawowych warunków uzyskiwania stopni i tytułów naukowych obowiązujących w okresie 1965-2003 przedstawiono w tabeli 1.

Obecnie obowiązujący porządek prawny w zakresie nadawania stopnia doktora habilitowanego i tytułu profesora wprowadziła ustawa z dnia 14 marca 2003 r., która została następnie znowelizowana w 2011 r. i 2014 r. 


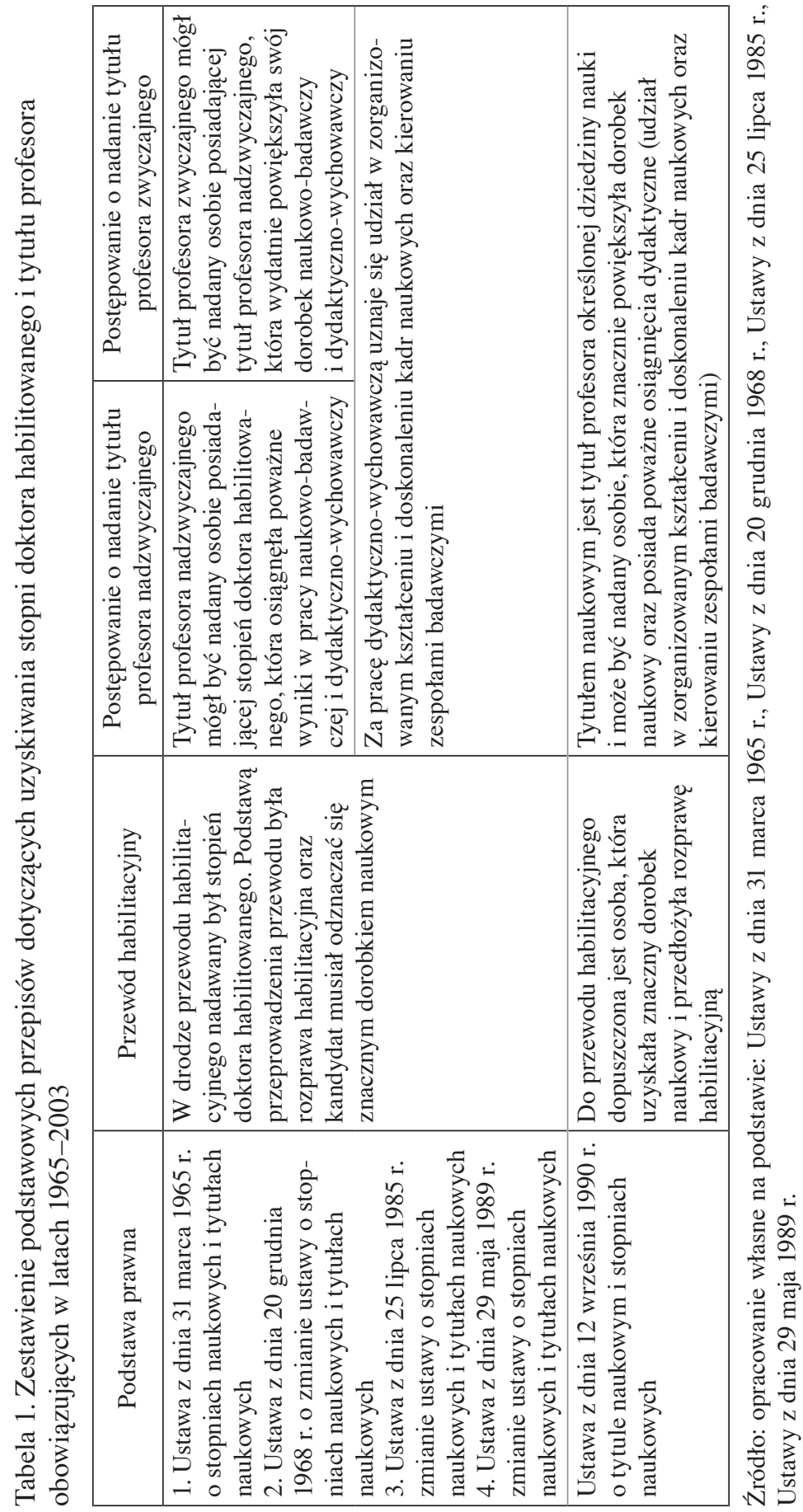


Rozwiązania z 2003 r. w zakresie nadawania stopnia doktora habilitowanego uznawały rozprawę habilitacyjną, pozostały dorobek naukowy oraz kolokwium habilitacyjne za podstawowe elementy uwzględniane przy ocenie kandydata. W przypadku postępowania zmierzającego do nadania tytułu profesora decyzja opierała się głównie na ocenie dorobku naukowego po uzyskaniu stopnia doktora habilitowanego i publikacji określanej „książką profesorską”. Obowiązujące uregulowania wzbudzały liczne dyskusje w środowiskach naukowych, których wyrazem było przyjęcie przez Ministerstwo Nauki i Szkolnictwa Wyższego w 2009 r. założeń dotyczących kierunków nowelizacji ustawy z 2003 r. Przyjęto trzy podstawowe kierunki zmian [Założenia do nowelizacji ustawy... 2009]:

- uproszczenia ścieżki awansu naukowego tak, aby perspektywa zdobywania kolejnych stopni oraz tytułu naukowego działała na naukowców motywująco i wspomagała ich rozwój naukowy,

- wprowadzenia przejrzystych procedur konkursowych na stanowiska uczelniane oraz szerszego otwarcia się uczelni na badaczy z zagranicy,

- usprawnienia funkcjonowania Centralnej Komisji do spraw Stopni i Tytułów, która będąc gwarantem zasad awansu naukowego, musi cieszyć się pełnym zaufaniem środowiska nauki.

Na bazie dyskusji przyjęta została ustawa z dnia 18 marca 2011 r. o zmianie ustawy - Prawo o szkolnictwie wyższym, ustawy o stopniach naukowych i tytule naukowym oraz o stopniach i tytule w zakresie sztuki oraz o zmianie niektórych innych ustaw. Równocześnie z realizacją przedstawionych powyżej postulatów nowelizacja ta znacznie podniosła wymagania w zakresie uzyskania tytułu naukowego profesora w porównaniu z przepisami z 2003 r., co wzbudziło w środowisku naukowym pewne obawy natury merytorycznej. Spowodowało to wyraźne zmniejszenie się liczby nadanych tytułów profesorskich, czego potwierdzeniem może być fakt, że - zgodnie ze Sprawozdaniem z działalności Centralnej Komisji do spraw Stopni i Tytułów - w 2013 r. Centralna Komisja wyznaczyła recenzentów w postępowaniach o nadanie tytułu profesora, wszczętych w trybie znowelizowanych przepisów, w stosunku do 10 wniosków (w 2012 r. - 4) [Sprawozdanie z działalności... 2013]. W tym samym dokumencie wyrażone zostały następujące obawy:

- czy postawione wymagania będą do spełnienia w naukach np. humanistycznych i społecznych,

- czy specjalista z zakresu filologii polskiej będzie mógł spełnić warunek staży i grantów zagranicznych,

- czy specjalista z zakresu historii lub prawa, gdzie ogromną większość badań wykonuje się indywidualnie, będzie w stanie wykazać się kierowaniem zespołami naukowymi realizującymi projekty badawcze.

Kolejna, przeprowadzona w 2014 r., nowelizacja ustawy o stopniach naukowych i tytule naukowym oraz o stopniach i tytule w zakresie sztuki z $2003 \mathrm{r}$. obniżyła wymagania stawiane kandydatom do tytułu naukowego profesora. 


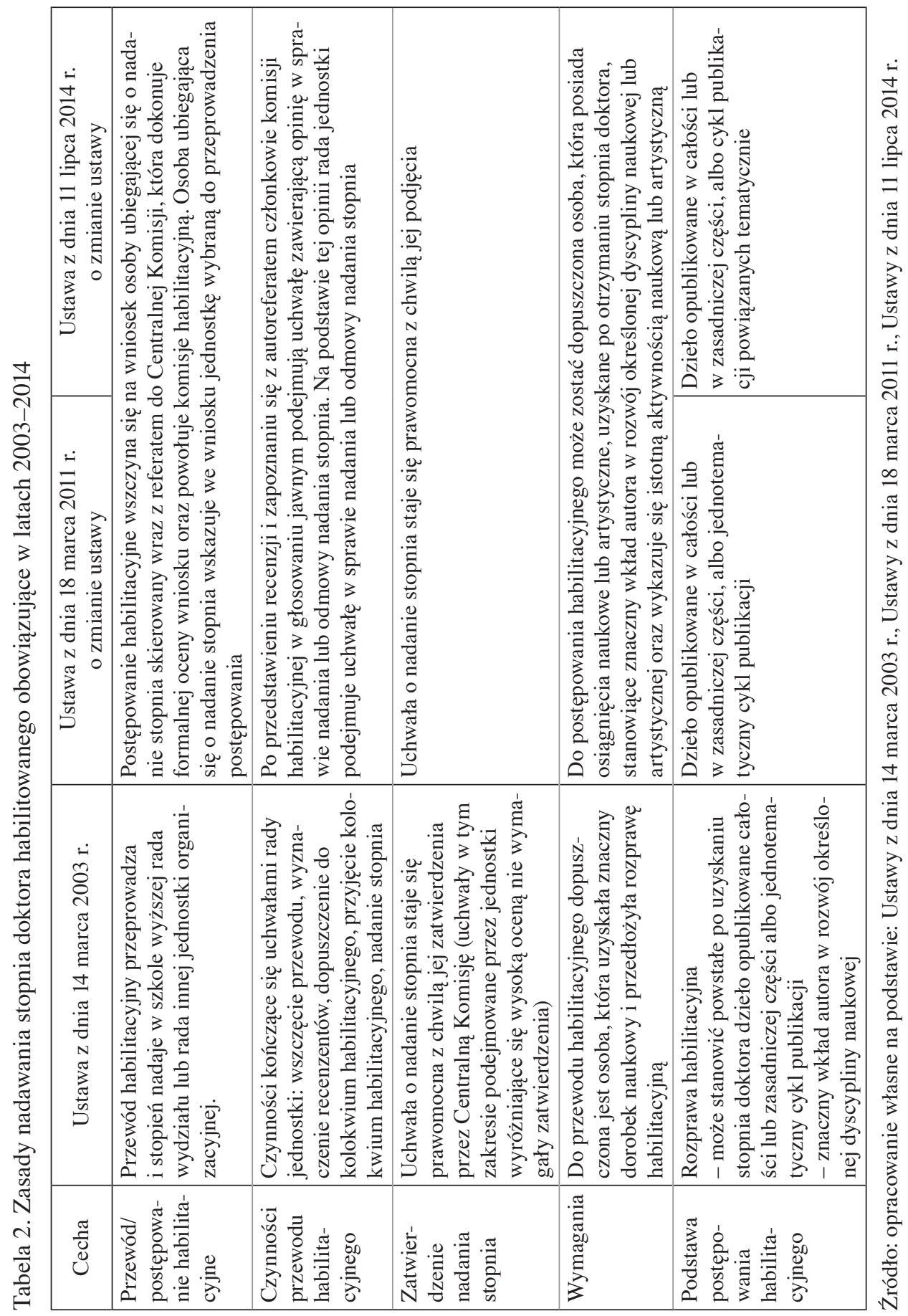




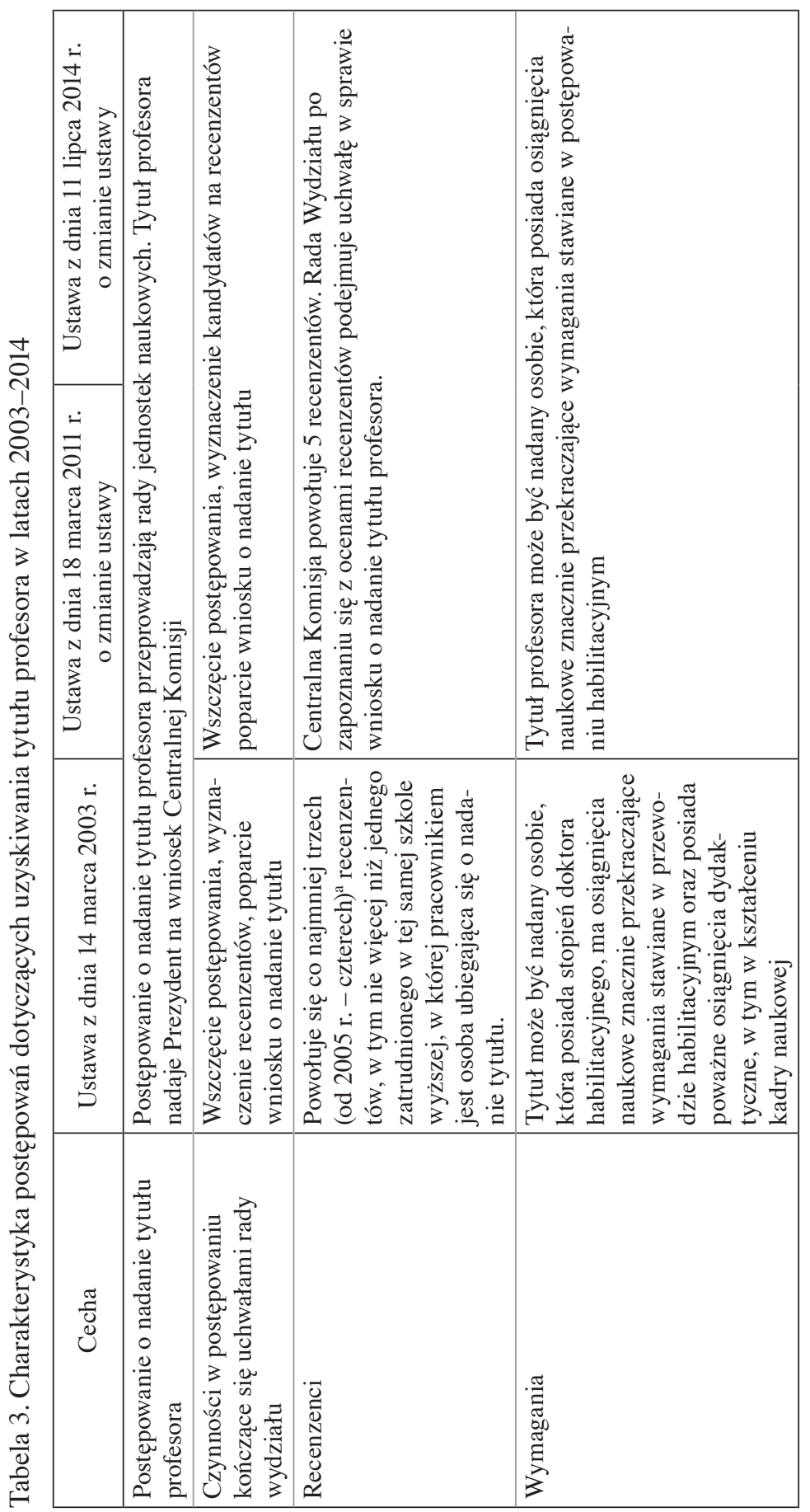




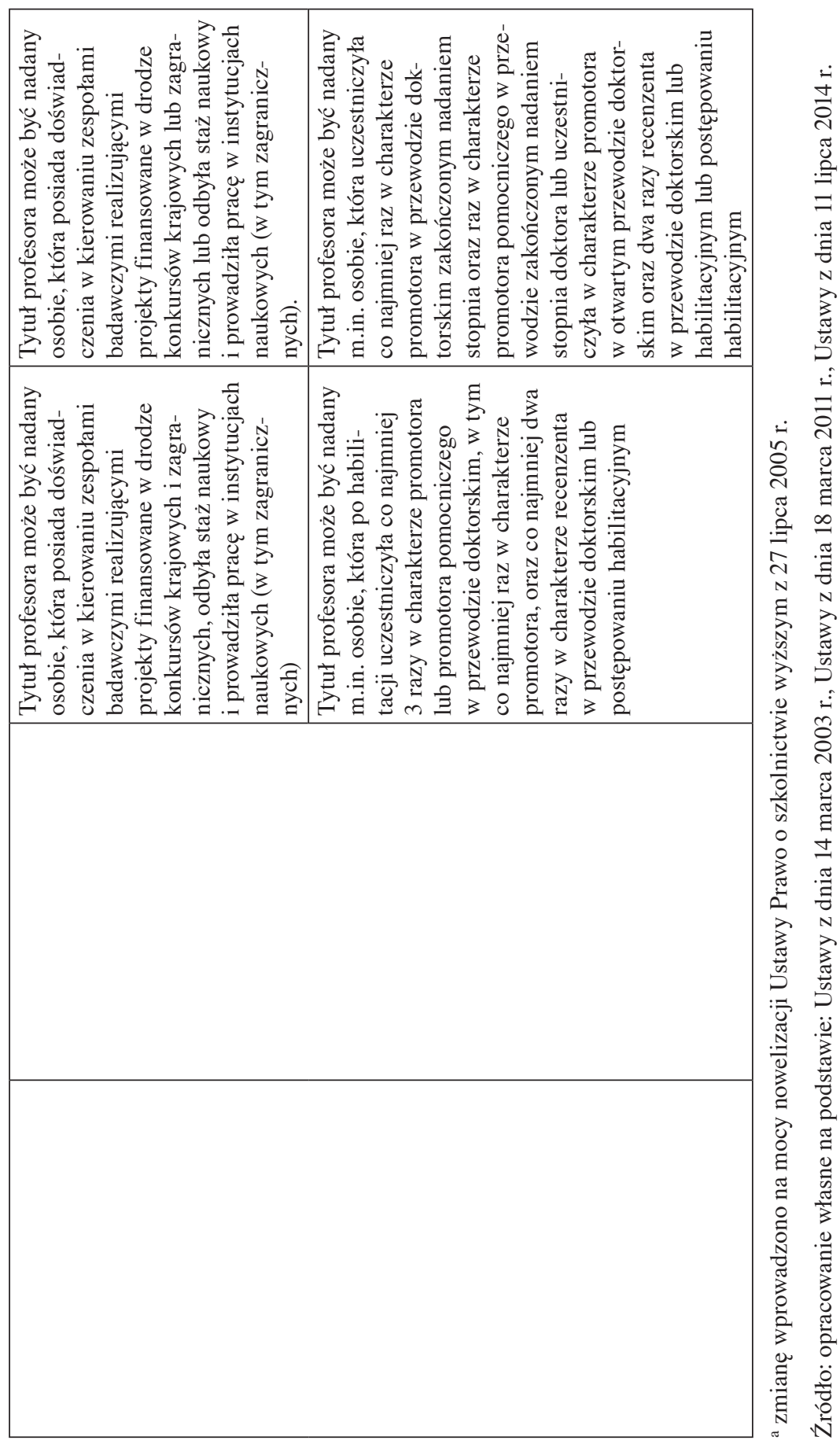


W tabeli 2 zestawiono kluczowe cechy rozwiązań dotyczących stopnia doktora habilitowanego wprowadzonych ustawą z 2003 r. i jej nowelizacjami z 2011 r. i 2014 r. W tabeli 3 zestawiono cechy charakterystyczne postępowań o nadanie tytułu profesora obowiązujących w okresie 2003-2014.

\subsection{Zasady zatrudniania na stanowiskach naukowo-dydaktycznych}

Wymagania co do polityki kadrowej prowadzonej na uczelniach w znacznym stopniu określa Ustawa Prawo o szkolnictwie wyższym z dnia 27 lipca 2005 r. z późn. zm. Zgodnie z art. 110 uczelnie wyższe zatrudniają pracowników będących nauczycielami akademickimi w podziale na stanowiska dydaktyczne i dydaktyczno-naukowe. Art. 116 ustawy stanowi, że statut uczelni może określać dodatkowe wymagania i kwalifikacje zawodowe osób zatrudnianych na stanowiskach naukowo-dydaktycznych oraz dydaktycznych. Podstawowe zapisy ustawy dotyczące zatrudniania na poszczególnych stanowiskach naukowo-dydaktycznych przedstawiono w tabeli 4.

Tabela 4. Charakterystyka stanowisk naukowo-dydaktycznych

\begin{tabular}{|c|c|c|c|}
\hline $\begin{array}{l}\text { Stanowisko naukowo- } \\
\text {-dydaktyczne }\end{array}$ & $\begin{array}{c}\text { Tytuł/stopień } \\
\text { naukowy }\end{array}$ & $\begin{array}{c}\text { Warunki } \\
\text { zatrudnienia }\end{array}$ & $\begin{array}{c}\text { Obowiązki w zakresie } \\
\text { działalności naukowo- } \\
\text {-badawczej }\end{array}$ \\
\hline Profesor zwyczajny & $\begin{array}{l}\text { Osoba posiadająca } \\
\text { tytuł naukowy pro- } \\
\text { fesora }\end{array}$ & $\begin{array}{l}\text { Statut uczelni określa } \\
\text { dodatkowe wyma- } \\
\text { gania i kwalifikacje } \\
\text { zawodowe }\end{array}$ & \multirow{3}{*}{$\begin{array}{l}\text { Kształcenie kadry } \\
\text { naukowej, prowadze- } \\
\text { nie badań naukowych } \\
\text { i prac rozwojowych, } \\
\text { rozwijanie twórczości } \\
\text { naukowej }\end{array}$} \\
\hline $\begin{array}{l}\text { Profesor nadzwy- } \\
\text { czajny }\end{array}$ & $\begin{array}{l}\text { Osoba posiadająca } \\
\text { stopień naukowy dok- } \\
\text { tora habilitowanego } \\
\text { lub tytuł naukowy } \\
\text { profesora }\end{array}$ & $\begin{array}{l}\text { Statut uczelni określa } \\
\text { dodatkowe wyma- } \\
\text { gania i kwalifikacje } \\
\text { zawodowe }\end{array}$ & \\
\hline Adiunkt & $\begin{array}{l}\text { Osoba, która posiada } \\
\text { co najmniej stopień } \\
\text { naukowy doktora }\end{array}$ & $\begin{array}{l}\text { Okres zatrudnienia na } \\
\text { stanowisku adiunkta } \\
\text { osoby nieposiadającej } \\
\text { stopnia naukowego } \\
\text { doktora habilitowa- } \\
\text { nego określa statut, } \\
\text { zatrudnienie na wska- } \\
\text { zanym stanowisku nie } \\
\text { może trwać dłużej niż } \\
8 \text { lat }\end{array}$ & \\
\hline
\end{tabular}


cd. tabeli 4

\begin{tabular}{|l|l|l|l|}
\hline $\begin{array}{c}\text { Stanowisko naukowo- } \\
\text {-dydaktyczne }\end{array}$ & \multicolumn{1}{|c|}{$\begin{array}{c}\text { Tytuł/stopień } \\
\text { naukowy }\end{array}$} & $\begin{array}{c}\text { Warunki } \\
\text { zatrudnienia }\end{array}$ & $\begin{array}{l}\text { Obowiązki w zakresie } \\
\text { działalności naukowo- } \\
\text {-badawczej }\end{array}$ \\
\hline Asystent & $\begin{array}{l}\text { Tytuł zawodowy magi- } \\
\text { stra lub tytuł równo- } \\
\text { rzędny }\end{array}$ & $\begin{array}{l}\text { Okres zatrudnienia na } \\
\text { stanowisku asystenta } \\
\text { osoby nieposiadającej } \\
\text { stopnia naukowego } \\
\text { doktora określa statut, } \\
\text { zatrudnienie na wska- } \\
\text { zanym stanowisku nie } \\
\text { może trwać dłużej niż } \\
8 \text { lat }\end{array}$ & $\begin{array}{l}\text { Prowadzenie badań } \\
\text { naukowych i prac } \\
\text { rozwojowych, } \\
\text { rozwijanie twórczości } \\
\text { naukowej }\end{array}$ \\
\hline
\end{tabular}

Źródło: opracowanie własne na podstawie Ustawy z dnia 27 lipca 2005 r. Prawo o szkolnictwie wyższym.

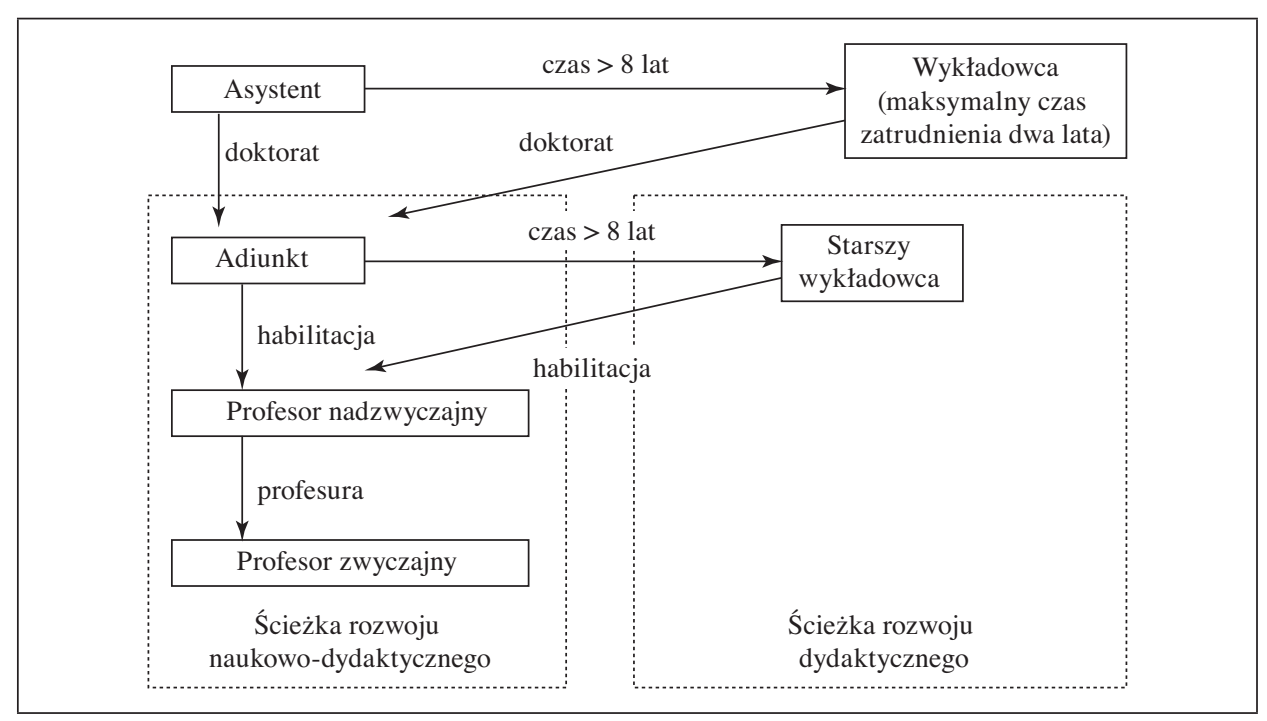

Rys. 1. Model kariery akademickiej w Uniwersytecie Ekonomicznym w Krakowie Źródło: opracowanie własne na podstawie Statutu Uniwersytetu Ekonomicznego w Krakowie z dnia 30 stycznia 2012 r., Zarządzenia Rektora z dnia 6 lipca 2010 r., Zarządzenia Rektora z dnia 20 stycznia $2014 \mathrm{r}$.

Model awansu pracownika naukowego jest determinowany momentem uzyskania stopni lub tytułu naukowego i polega na obejmowaniu coraz wyższych w hierarchii naukowej stanowisk. Rozwój naukowy zależy od stopnia zaangażowania pracownika, przepisów prawa oraz polityki personalnej prowadzonej w uczelni. Na rys. 1 zaprezentowany został model kariery nauczyciela akademic- 
kiego zatrudnionego na Uniwersytecie Ekonomicznym w Krakowie obowiązujący w tej uczelni.

\section{Analiza procesu uzyskiwania stopnia doktora habilitowanego przez pracowników Uniwersytetu Ekonomicznego w Krakowie w latach 1970-2014}

Badania przeprowadzano na podstawie danych dotyczących 525 osób, którzy przynajmniej przez pewną część lat ${ }^{1} 1970-2014$ byli pracownikami uczelni i posiadali stopień naukowy doktora. Przyjęto, że osoby te stanowią grupę kandydatów do uzyskania stopnia doktora habilitowanego.

Liczba habilitacji uzyskanych przez pracowników UEK w analizowanym okresie przedstawiona została na rys. 2. Oszacowana funkcja trendu wskazuje na tendencję wzrostową.

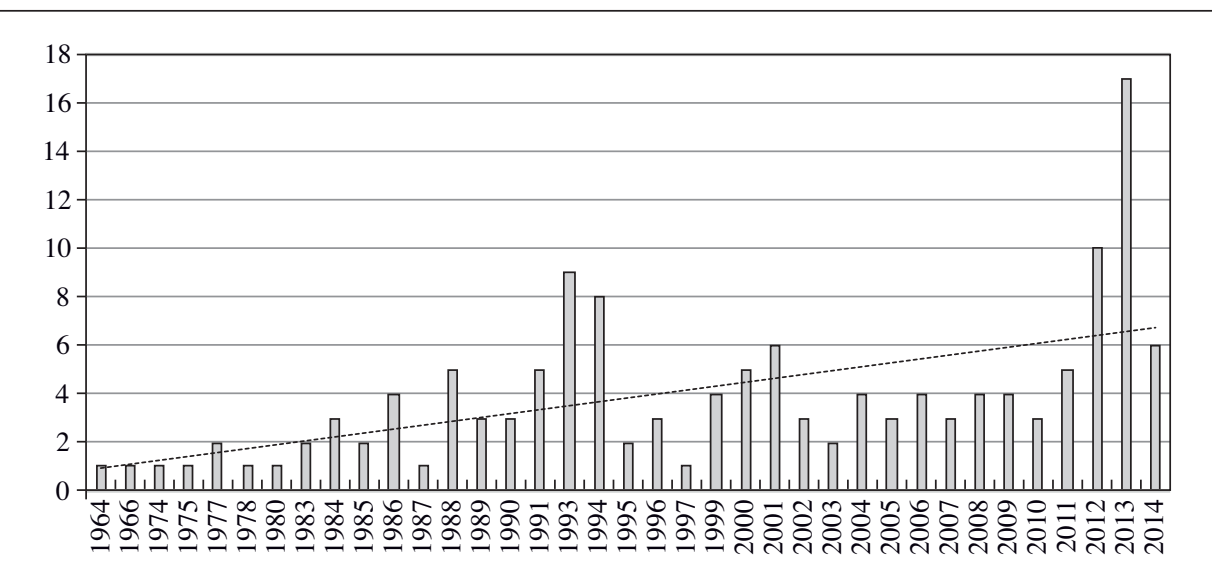

Rys. 2. Liczba uzyskanych stopni doktora habilitowanego przez pracowników Uniwersytetu Ekonomicznego w Krakowie w latach 1964-2014

Źródło: opracowanie własne.

Liczbę uzyskanych stopni doktora habilitowanego na tle informacji o liczbie osób, które powinny były ten stopień uzyskać, przedstawiono w tabeli 5.

Skuteczność procesu uzyskiwania habilitacji można wyrazić w sposób zagregowany poprzez porównanie liczby osób, które uzyskały ten stopien, do liczby osób, które powinny go uzyskać. W trakcie obliczeń uwzględniono jedynie te

\footnotetext{
${ }^{1} \mathrm{~W}$ trakcie realizacji badań (wrzesień 2014 r.) nie były jeszcze dostępne pełne dane dotyczące $2014 \mathrm{r}$.
} 
osoby, które uzyskały stopień doktora do 2005 r. włącznie (aby określić liczbę osób zobligowanych przez przepisy prawne do uzyskania stopnia doktora habilitowanego). Sposób kształtowania się współczynnika skuteczności dla analizowanej grupy pracowników przedstawia tabela 6.

Tabela 5. Liczebność grupy pracowników posiadających stopień doktora, objętej badaniem według płci oraz z podziałem na osoby, które uzyskały stopień do $2005 \mathrm{r}$. lub po $2005 \mathrm{r}$.

\begin{tabular}{|l|c|c|c|}
\hline \multicolumn{1}{|c|}{ Wyszczególnienie } & Kobiety & Mężczyźni & Razem \\
\hline \multicolumn{4}{|c|}{ Osoby, które uzyskały stopień doktora habilitowanego } \\
\hline Liczba osób, które uzyskały stopień doktora po 2005 r. & 0 & 6 & 6 \\
\hline Liczba osób, które uzyskały stopien doktora do 2005 r. & 39 & 97 & 136 \\
\hline Razem & 39 & 103 & 142 \\
\hline \multicolumn{5}{|c|}{ Osoby, które nie uzyskały stopnia doktora habilitowanego } \\
\hline Liczba osób, które uzyskały stopien doktora po 2005 r. & 89 & 102 & 191 \\
\hline Liczba osób, które uzyskały stopień doktora do 2005 r. & 95 & 97 & 192 \\
\hline Razem & 184 & 199 & 383 \\
\hline \multicolumn{5}{|c|}{ Ogółem } & 89 & 108 & 197 \\
\hline Liczba osób, które uzyskały stopień doktora po 2005 r. & 134 & 194 & 328 \\
\hline Liczba osób, które uzyskały stopień doktora do 2005 r. & 223 & 302 & 525 \\
\hline Razem
\end{tabular}

Źródło: opracowanie własne.

Tabela 6. Wartość współczynnika skuteczności uzyskania stopnia doktora habilitowanego przez pracowników, którzy w latach 1970-2005 uzyskali stopień doktora

\begin{tabular}{|c|c|c|}
\hline Kobiety & Mężczyźni & Razem \\
\hline $39 / 134=0,29$ & $97 / 194=0,50$ & $136 / 328=0,41$ \\
\hline
\end{tabular}

Źródło: opracowanie własne.

Tabela 7. Czas uzyskania stopnia doktora habilitowanego (w latach)

\begin{tabular}{|l|c|c|c|}
\hline \multicolumn{1}{|c|}{ Wyszczególnienie } & Kobiety & Mężczyźni & Razem \\
\hline Liczba osób & 39 & 103 & 142 \\
\hline Średnia & 14,44 & 12,45 & 12,99 \\
\hline Odchylenie standardowe & 4,42 & 5,57 & 5,34 \\
\hline Mediana & 14 & 12 & 12 \\
\hline Okres minimalny & 6 & 3 & 3 \\
\hline Okres maksymalny & 24 & 39 & 39 \\
\hline
\end{tabular}

Źródło: opracowanie własne. 
Interesująca również może być analiza danych dotyczących czasu niezbędnego do uzyskania stopnia doktora habilitowanego. Czas ten wyraża liczbę lat w okresie pomiędzy uzyskaniem stopnia doktora i doktora habilitowanego.

Kształtowanie się czasu niezbędnego do uzyskania stopnia doktora habilitowanego w badanym okresie przedstawia rys. 3 .

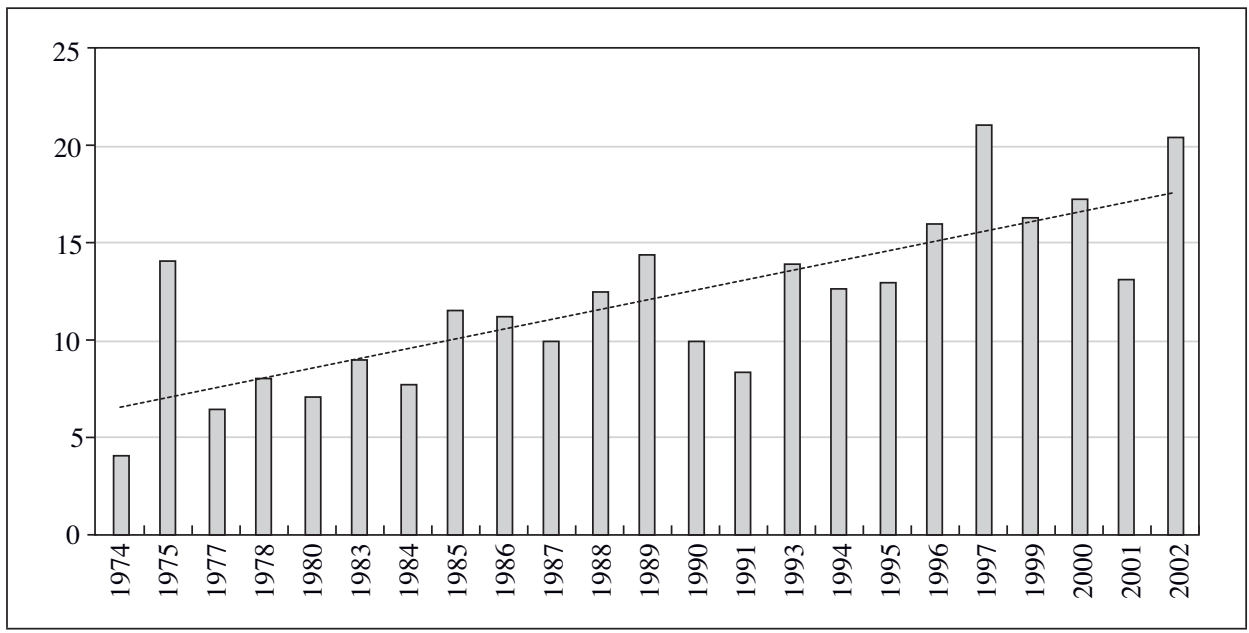

Rys. 3. Czas niezbędny do uzyskania stopnia doktora habilitowanego (w latach) Źródło: opracowanie własne.

Dane przedstawione na rys. 3 wskazują, że długość średniego czasu niezbędnego do uzyskania stopnia doktora habilitowanego wzrasta.

W kolejnym kroku badań wykorzystano wybrane narzędzia badawcze dostarczane przez analizę przeżycia (por. [Balicki 2006]). Za wykorzystaniem metod należących do tej grupy przemawia przede wszystkim ucięty charakter danych będących podstawą obliczeń. Przeprowadzone obliczenia miały na celu obliczenie charakterystyk pokazujących możliwość pojawienia się zdarzenia, jakim jest uzyskanie stopnia doktora habilitowanego w kolejnych latach mijających od roku uzyskania stopnia doktora.

Wykorzystując zgromadzone zasoby informacyjne, oszacowano między innymi:

- funkcję przeżycia - pokazującą odsetek osób, które w trakcie kolejnych lat od roku uzyskania stopnia doktora, nie uzyskały stopnia doktora habilitowanego,

- współczynnik hazardu - będący prawdopodobieństwem, że osoba w danym roku od momentu uzyskania doktoratu, zdobędzie stopień doktora habilitowanego.

Kształtowanie się funkcji przeżycia pokazano na rys. 4. 
Analiza kształtowania się przebiegu funkcji wskazuje, że w wielu przypadkach czas potrzebny do uzyskania stopnia doktora habilitowanego jest dłuższy niż założony w ustawie. Szczególnie niepokojący jest fakt, że funkcja przeżycia stabilizuje się na dość wysokim poziomie, co wskazuje na wysoki odsetek osób, które nigdy nie uzyskały stopnia doktora habilitowanego.

Współczynnik hazardu kształtował się w sposób pokazany na rys. 5.

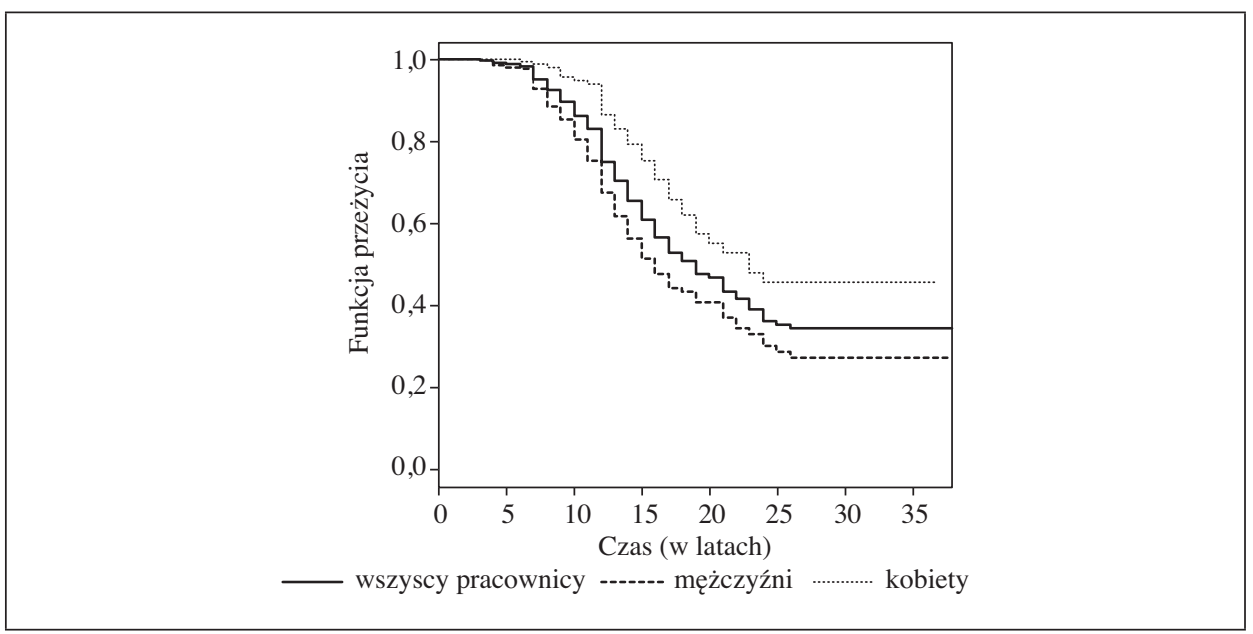

Rys. 4. Funkcja przeżycia - habilitacje

Źródło: opracowanie własne.

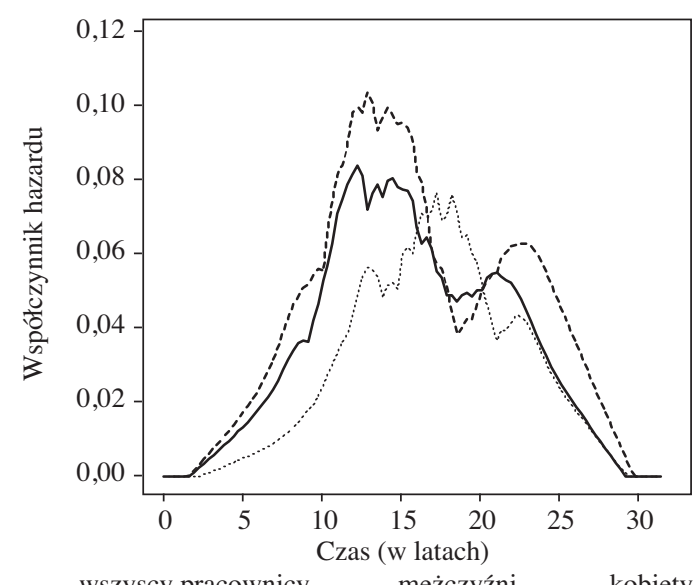

Rys. 5. Współczynnik hazardu - habilitacje

Źródło: opracowanie własne. 
Sposób kształtowania się współczynnika pokazuje, w jaki sposób zmienia się prawdopodobieństwo uzyskania stopnia doktora habilitowanego w kolejnych latach od momentu uzyskania stopnia doktora. Wartość maksymalna jest o kilka lat przesunięta w prawo w stosunku do wymagań ustawowych. W przypadku mężczyzn widoczne są dwa wyraźne maksima. W przypadku kobiet można wskazać na trzy ekstrema, przy czym jedno z nich ma charakter dominujący.

\section{Analiza procesu uzyskiwania tytułu profesora przez pracowników Uniwersytetu Ekonomicznego w Krakowie w latach 1970-2014}

Badania przeprowadzano na podstawie danych dotyczących 141 osób, którzy przynajmniej przez pewną część okresu² 1970-2014 byli pracownikami uczelni i posiadali stopień naukowy doktora habilitowanego. Przyjęto, że osoby te stanowią grupę kandydatów do uzyskania tytułu naukowego profesora.

Liczba tytułów naukowych profesora uzyskanych przez pracowników UEK w analizowanym okresie przedstawiona została na rys. 6. Oszacowana funkcja trendu wskazuje tendencję wzrostową.

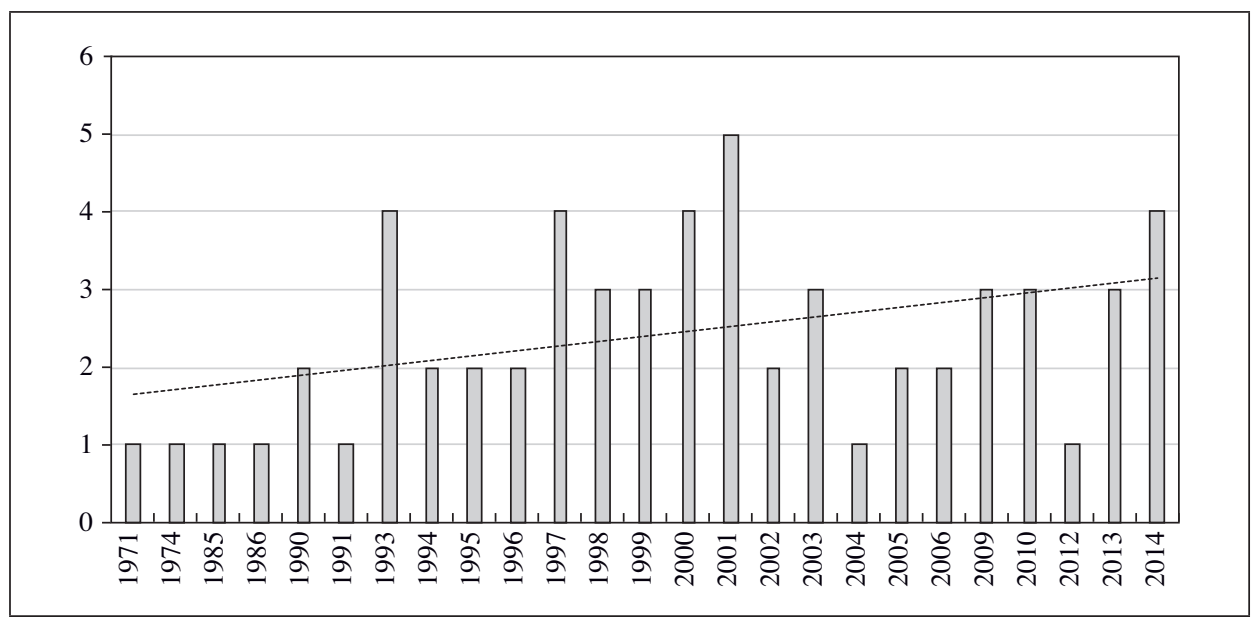

Rys. 6. Liczba uzyskanych tytułów naukowych profesora przez pracowników Uniwersytetu Ekonomicznego w Krakowie w latach 1971-2014 Źródło: opracowanie własne.

${ }^{2} \mathrm{~W}$ trakcie realizacji badań (wrzesień 2014 r.) nie były jeszcze dostępne pełne dane dotyczące $2014 \mathrm{r}$. 
Dane pokazujące liczbę uzyskanych tytułów naukowych profesora na tle informacji o liczbie osób, które powinny były ten tytuł uzyskać przedstawione zostały w tabeli 8.

Tabela 8. Liczebność grupy pracowników posiadających stopień doktora habilitowanego, objętej badaniem według płci oraz z podziałem na osoby, które uzyskały stopień do 2004 r. lub po $2004 \mathrm{r}$.

\begin{tabular}{|c|c|c|c|}
\hline Wyszczególnienie & Kobiety & Mężczyźni & Razem \\
\hline \multicolumn{4}{|c|}{ Osoby, które uzyskały tytuł profesora } \\
\hline $\begin{array}{l}\text { Liczba osób, które uzyskały stopień doktora habilitowa- } \\
\text { nego po } 2004 \text { r. }\end{array}$ & 1 & 0 & 1 \\
\hline $\begin{array}{l}\text { Liczba osób, które uzyskały stopień doktora habilitowa- } \\
\text { nego do } 2004 \text { r. }\end{array}$ & 16 & 43 & 59 \\
\hline Razem & 17 & 43 & 60 \\
\hline \multicolumn{4}{|c|}{ Osoby, które nie uzyskały tytułu profesora } \\
\hline $\begin{array}{l}\text { Liczba osób, które uzyskały stopień doktora habilitowa- } \\
\text { nego po } 2004 \text { r. }\end{array}$ & 15 & 42 & 57 \\
\hline $\begin{array}{l}\text { Liczba osób, które uzyskały stopień doktora habilitowa- } \\
\text { nego do } 2004 \text { r. }\end{array}$ & 7 & 17 & 24 \\
\hline Razem & 22 & 59 & 81 \\
\hline \multicolumn{4}{|l|}{ Ogółem } \\
\hline $\begin{array}{l}\text { Liczba osób, które uzyskały stopień doktora habilitowa- } \\
\text { nego po } 2004 \text { r. }\end{array}$ & 16 & 42 & 58 \\
\hline $\begin{array}{l}\text { Liczba osób, które uzyskały stopień doktora habilitowa- } \\
\text { nego do } 2004 \text { r. }\end{array}$ & 23 & 60 & 83 \\
\hline Razem & 39 & 102 & 141 \\
\hline
\end{tabular}

Źródło: opracowanie własne.

Skuteczność procesu uzyskiwania tytułu profesora została obliczona w podobny sposób jak w przypadku analizy habilitacji. Przyjęto, że jest to stosunek liczby osób, które uzyskały tytuł profesora i liczby osób, które powinny były go uzyskać (za takie osoby uznano w badaniach te, które uzyskały stopień doktora habilitowanego do 2004 r. włącznie). Sposób kształtowania się współczynnika skuteczności dla analizowanej grupy pracowników przedstawia tabela 9.

Tabela 9. Wartość współczynnika skuteczności uzyskania tytułu naukowego przez pracowników, którzy w latach 1970-2004 uzyskali stopień doktora habilitowanego

\begin{tabular}{|c|c|c|}
\hline Kobiety & Mężczyźni & Razem \\
\hline $16 / 23=0,70$ & $43 / 60=0,72$ & $59 / 83=0,71$ \\
\hline
\end{tabular}

Źródło: opracowanie własne. 
Interesująca również może być analiza danych dotyczących czasu niezbędnego do uzyskania tytułu naukowego profesora. Czas ten wyraża liczbę lat w okresie pomiędzy uzyskaniem stopnia doktora habilitowanego i tytułu profesora.

Tabela 10. Czas uzyskania tytułu naukowego profesora (w latach)

\begin{tabular}{|l|c|c|c|}
\hline \multicolumn{1}{|c|}{ Wyszczególnienie } & Kobiety & Mężczyźni & Razem \\
\hline Liczba osób & 17 & 43 & 60 \\
\hline Średnia & 11,47 & 10,16 & 10,53 \\
\hline Odchylenie standardowe & 2,96 & 3,21 & 3,17 \\
\hline Mediana & 11 & 9 & 10 \\
\hline Okres minimalny & 7 & 6 & 6 \\
\hline Okres maksymalny & 17 & 20 & 20 \\
\hline
\end{tabular}

Źródło: opracowanie własne.

Kształtowanie się czasu niezbędnego do uzyskania tytułu naukowego profesora w badanym okresie przedstawia rys. 7. Dane przedstawione na rysunku wskazują, że długość czasu niezbędnego do uzyskania tytułu naukowego wydłuża się.

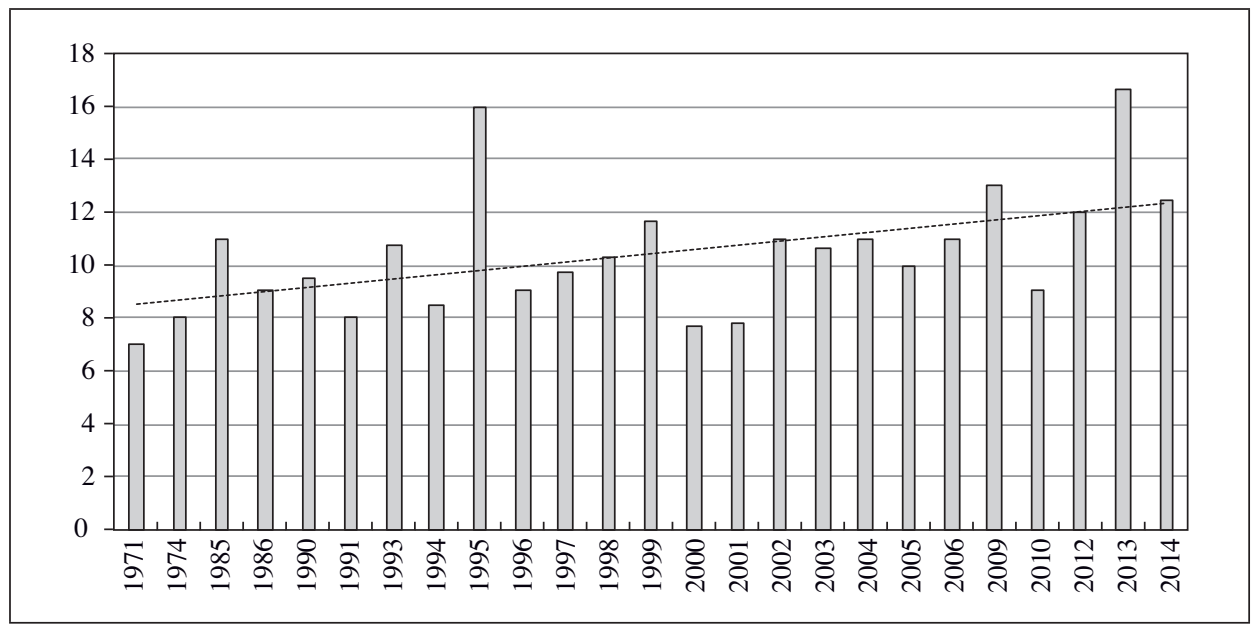

Rys. 7. Czas niezbędny do uzyskania tytułu profesora (w latach) Źródło: opracowanie własne.

W kolejnym kroku badań, analogicznie jak w przypadku analizy dotyczącej uzyskanych stopni doktora habilitowanego, wykorzystano wybrane narzędzia badawcze dostarczane przez analizę przeżycia ze względu na ucięty charakter danych będących podstawą obliczeń. Przeprowadzone obliczenia miały na celu 
obliczenie charakterystyk pokazujących możliwość pojawienia się zdarzenia, jakim jest uzyskanie tytułu naukowego profesora w kolejnych latach mijających od roku uzyskania stopnia doktora habilitowanego.

Wykorzystując zgromadzone zasoby informacyjne, oszacowano między innymi:

- funkcję przeżycia - pokazującą odsetek osób, które w trakcie kolejnych lat od roku uzyskania stopnia doktora habilitowanego, nie uzyskały tytułu naukowego profesora,

- współczynnik hazardu - będący prawdopodobieństwem, że osoba w danym roku od momentu uzyskania habilitacji, uzyska tytuł naukowy profesora.

Kształtowanie się funkcji przeżycia przedstawiono na rys. 8.

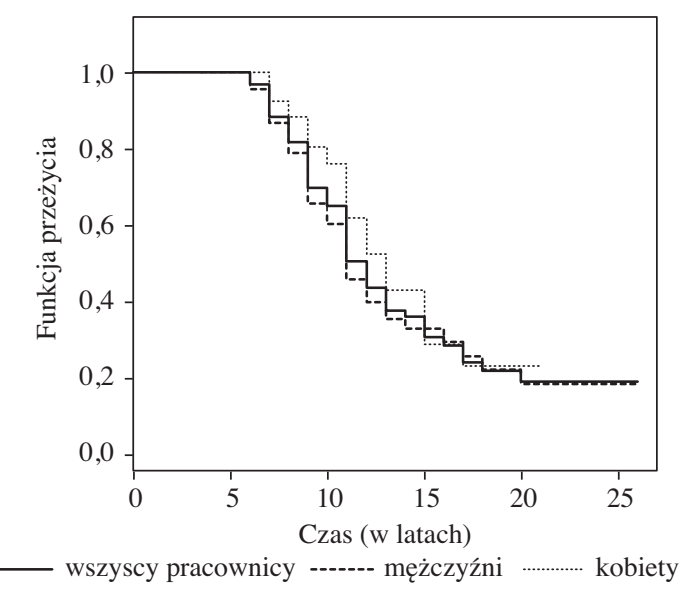

Rys. 8. Funkcja przeżycia - profesura

Źródło: opracowanie własne.

Analiza kształtowania się przebiegu funkcji potwierdza, że w wielu przypadkach czas potrzebny do uzyskania tytułu naukowego profesora jest dłuższy niż dekada. Szczególnie niepokojący jest fakt, że funkcja przeżycia stabilizuje się na dość wysokim poziomie, co wskazuje na wysoki odsetek osób, które nigdy nie uzyskały tytułu naukowego profesora.

Współczynnik hazardu kształtował się w sposób pokazany na rys. 9. Sposób kształtowania się współczynnika pokazuje, w jaki sposób zmienia się prawdopodobieństwo uzyskania tytułu naukowego profesora w kolejnych latach od momentu uzyskania stopnia doktora habilitowanego. Prawdopodobieństwo uzyskania tytułu profesora osiąga wartość maksymalną po upływie 10 lat. Zarówno w przypadku 
mężczyzn jak i kobiet można wskazać na trzy ekstrema, przy czym jedno w przypadku mężczyzn ma charakter dominujący.

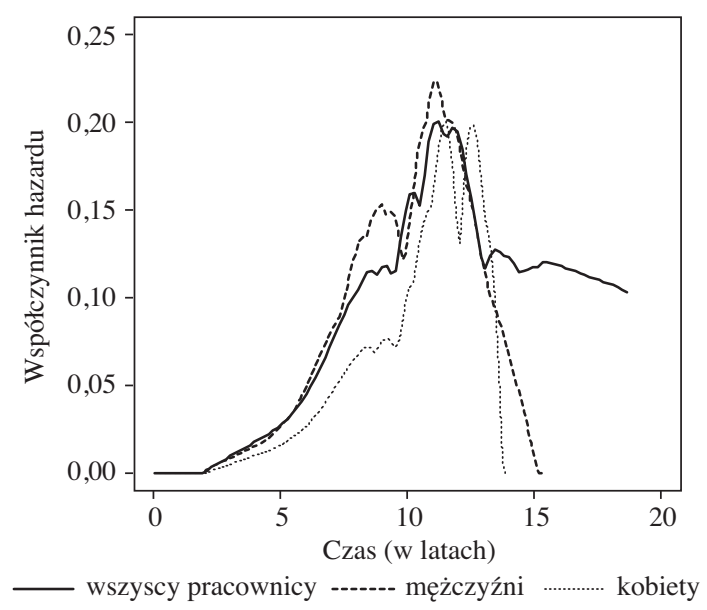

Rys. 9. Współczynnik hazardu - profesura

Źródło: opracowanie własne.

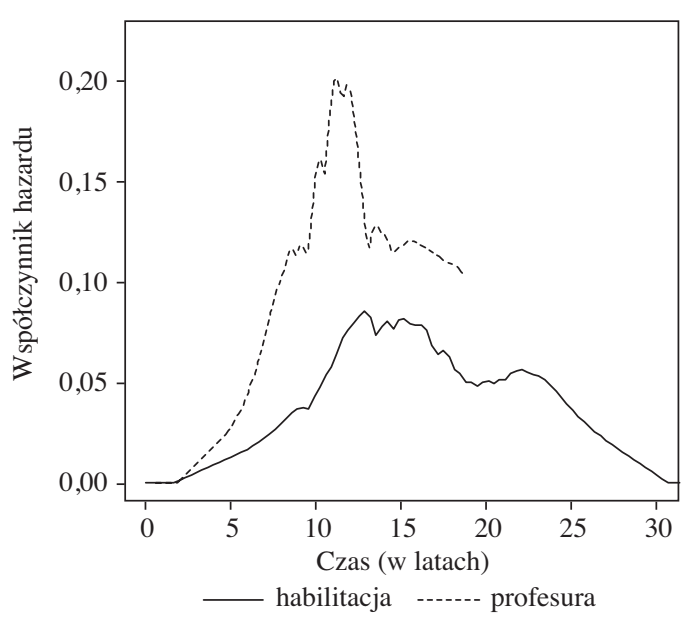

Rys. 10. Współczynnik hazardu dla habilitacji i profesury

Źródło: opracowanie własne. 
Interesujące może być porównanie współczynnika hazardu obliczonego na podstawie danych dotyczących uzyskiwania stopnia doktora habilitowanego i tytułu profesora (rys. 10). Prawdopodobieństwo uzyskania tytułu profesora w kolejnych latach od uzyskania habilitacji jest znacznie wyższe niż prawdopodobieństwo uzyskania stopnia doktora habilitowanego kolejnych w latach po doktoracie.

\section{Wnioski}

1. Rozwój naukowy pracowników jest podstawowym czynnikiem gwarantującym istnienie i rozwój uniwersytetu.

2. Wydaje się, że konieczne jest prowadzenie przez władze uczelni właściwej polityki mającej na celu:

- zwiększenie liczby osób zdobywających stopnie i tytuły naukowe (szczególnie jest to istotne w przypadku habilitacji),

- skrócenie czasu niezbędnego do uzyskiwania kolejnych etapów w drodze awansu naukowego.

3. Należy przeprowadzić identyfikację czynników mających istotny wpływ na szybkość i jakość postępowań awansowych.

\section{Literatura}

Balicki A. [2006], Analiza przeżycia i tablice wymieralności, PWE, Warszawa.

Sprawozdanie z działalności Centralnej Komisji do spraw Stopni i Tytułów w 2013 r. http://www.ck.gov.pl/index.php?option=com_content \&view=article \&id=10\&Ite$\operatorname{mid}=24$.

Statut Uniwersytetu Ekonomicznego w Krakowie załącznik do Uchwały Senatu nr 4/2012 z dnia 30 stycznia 2012 r. zmieniony uchwałami nr 21/2012 z dnia 25 czerwca 2012 r., nr 24/2012 z dnia 17 września 2012 r. i nr 3/2014 z dnia 27 stycznia 2014 r.

Ustawa z dnia 31 marca 1965 r. o stopniach naukowych i tytułach naukowych.

Ustawa z dnia 20 grudnia 1968 r. o zmianie ustawy o stopniach naukowych i tytułach naukowych.

Ustawa z dnia 25 lipca 1985 r. zmianie ustawy o stopniach naukowych i tytułach naukowych.

Ustawa z dnia 29 maja 1989 r. zmianie ustawy o stopniach naukowych i tytułach naukowych.

Ustawa z dnia 12 września 1990 r. o tytule naukowym i stopniach naukowych.

Ustawa z dnia 14 marca 2003 r. o stopniach naukowych i tytule naukowym oraz stopniach i tytule w zakresie sztuki.

Ustawa z dnia 27 lipca 2005 r. Prawo o szkolnictwie wyższym. 
Ustawa z dnia 18 marca 2011 r. o zmianie ustawy - Prawo o szkolnictwie wyższym, ustawy o stopniach naukowych i tytule naukowym oraz o stopniach i tytule w zakresie sztuki oraz o zmianie niektórych innych ustaw.

Ustawa z dnia 11 lipca 2014 r. o zmianie ustawy - Prawo o szkolnictwie wyższym oraz niektórych innych ustaw.

Założenia do nowelizacji ustawy - Prawo o szkolnictwie wyższym oraz ustawy o stopniach naukowych i tytule naukowym oraz o stopniach i tytule w zakresie sztuki. Projekt z dnia 16 października 2009 r. uwzględniający zalecenia stałego Komitetu Rady Ministrów z dnia 15 października 2009 r., Ministerstwo Nauki i Szkolnictwa Wyższego http://www.bip.nauka.gov.pl/g2/oryginal/2013_05/a77439f526899374e5924d6156f35dc3.pdf.

Zarządzenia Rektora Uniwersytetu Ekonomicznego w Krakowie nr R-0121-44/2010 z dnia 6 lipca 2010 r. w sprawie zasad zatrudniania i awansowania pracowników w Uniwersytecie Ekonomicznym w Krakowie.

Zarządzenia Rektora Uniwersytetu Ekonomicznego w Krakowie nr R-0201-3/2014 z dnia 20 stycznia $2014 \mathrm{r}$.

\section{Analysis and Modeling of the Scientific Development of Academic Employees (Abstract)}

The aim of the paper is to analyse the process associated with scientific development of faculty at institutions of higher learning. The career path of a member of faculty is determined by the scientific degree and titles he or she earns or by taking up consecutive positions at university. The development is determined by the faculty member's personal involvement, regulations and the personnel policy of the university.

In this paper, survival analysis was the main tool used to create a model of scientific development. The data used for the analysis concern PhD degrees earned and professorships conferred uponfaculty members at the University of Economicsin Cracow in the years 1970-2014.

Keywords: survival function, hazard rate, scientific developments, universities. 